\title{
ESTIMATION OF UHMWPE CRYSTALLINITY DEGREE VARIATION
}

\author{
Michat Sobociński \\ Institute of Mechanical Technology, Czestochowa University of Technology \\ Częstochowa, Poland \\ sobocinski@iop.pcz.pl
}

\begin{abstract}
The paper presents thermal analysis as far as tests on polymers are concerned. The obtained results, after being mathematically elaborated, differentiate thermal processes and define normal heat. It also consists of mathematical elaboration of the tests as well as an explanation of the graphical results. The paper also presents the empirical results of the tests conducted on polymers crystallinity variation submitted to one of the factors influencing the change of the material parameters.
\end{abstract}

Keywords: thermal analysis, degree of crystallinity

\section{Differential Scanning Calorimetry (DSC) in tests on polymers}

Differential Scanning Calorimetry is one of the basic methods of thermal analysis widely used in tests on polymers.

The DSC method is used in tests on:

- Polymers phase processes

- Physical processes: glass transition $T_{g}$, softening point $T_{m}$

- Mixtures' ingredients and copolymers

- Thermal transition $T_{d}$ (temperature of destruction) of polymers, oxidation and combustion

- Heat: cristalisation, polimerisation, dissolution, absorption and desorption

- Melting enthalpy and crystallinity degree

The purpose of Differential Scanning Calorimetry (DSC) is to define the change of heat streams inducted into the sample $\Phi_{S}$ and to the reference sample $\Phi_{R}$ occurring under the influence of the given temperature to the samples, and an attempt to estimate the importance of the temperature $[1,2]$ :

$$
\Delta \Phi_{S R}=\Phi_{S}-\Phi_{R}
$$

where:

$\Phi_{S}$ - sample heat stream,

$\Phi_{R}$ - reference sample heat stream. 
The results of DSC measurements is the curve line DSC - the dependence of the measured heat streams on the time/temperature. The most common temperature regime is the change of it with a constant speed

$$
\beta \equiv \frac{\Delta T}{\Delta t}=\mathrm{const}
$$

foreseen in advance, independent on the sample parameters change, commonly called an average speed of heating. An example of such dependence is shown in Figure 1.

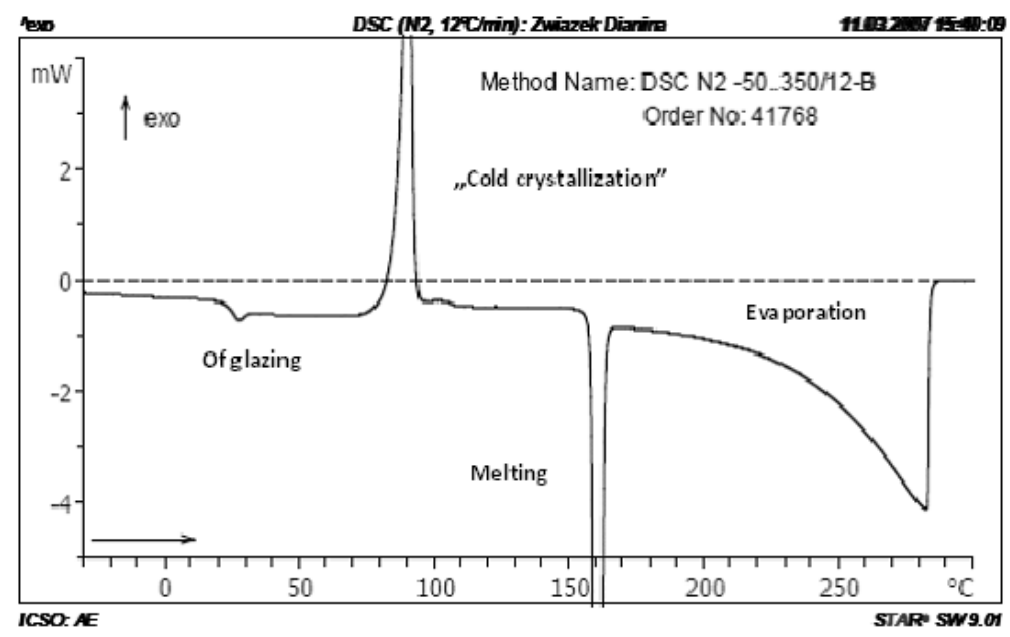

Fig. 1. The curve line DSC and example of physical processes occurring while heating the sample [2]

The crystallinity phase in polymer is defined as crystallinity degree. Crystal polymers have particular temperature of decomposition $T_{t}$. Heating the polymer causes the decrease of crystallinity degree, as the crystal phase changes into the amorphic one. The melted polymer has only the amorphic phase. Polymers crystality degree can be defined as fractional consistence of crystality phase in the polymer sample.

The above definition is based on a so-called double phase model. In fact, it applies mostly to homopolymers. But it is also possible to use it for homopolymer mixtures and copolymers.

Chemical reactions and processes where the heat is used or emitted are visible on the curie line DSC as a reflex up or down from the zero line. Those going down stand for egzothermal processes (i.e. cristalisation), and those going up stand for endothermal ones (i.e. melting). Defining crystallinity degree by DSC method is one of the most commonly used empirical methods and is marked as $\omega_{c, h}$. The curve line obtained in the DSC test is presented as dependence: 


$$
\frac{d Q}{d t}=m \cdot c_{p} \cdot \frac{d T}{d t}
$$

where:

$m$ - mass of the sample,

$c_{p}$ - specific heat with constant pressure (thermal capacity for mass unit),

$\frac{d Q}{d t}$ - heat provided or emitted from the system in time unit,

$\frac{d T}{d t}$ - heating or cooling speed.

Specific heat $c_{p}$ is one of the basic thermal parameters of each material. Precisely, $c_{p}$ can be marked as differential function:

$$
c(T)=\frac{1}{m}\left(\frac{d Q}{d T}\right)
$$

While measuring, when the heating speed is constant $(\beta=$ const), it is assumed that the heat streams to the sample and from the reference sample are settled and of the values:

$$
\begin{aligned}
& \Phi_{S}=C_{S} \cdot \frac{d T_{S}}{d t} \approx C_{S} \cdot \beta \\
& \Phi_{R}=C_{R} \cdot \frac{d T_{R}}{d t} \approx C_{R} \cdot \beta
\end{aligned}
$$

where: $C_{S}, C_{R}$ - thermal capacity of the sample/reference sample.

In order to properly conduct the analysis it is important to obtain the so-called correction signal of geometrical asymmetry of calorimeter by measuring the blanks.

$$
\begin{aligned}
& m_{N, S}=m_{N, R} \\
& m_{R}=0 \\
& m_{S}=\text { const } \\
& \Phi_{m}(T)=\Phi_{m}(T)-\Phi_{m}^{0}(T)=m_{S} \cdot c_{S}(T) \cdot \beta
\end{aligned}
$$

Finally, the specific heat is defined as [3]:

$$
c_{S}(T)=\frac{\Phi_{m}(T) \pm \Delta m_{N, S} \cdot c_{N}(T) \cdot \beta}{m_{S} \cdot \beta}
$$


When using the DSC method it is advised to apply the following cristality degree definition:

$$
\omega_{c, h}=\frac{\Delta h_{t}}{\Delta h_{t, c}}
$$

where:

$\Delta h_{t}$ - melting temperature of the sample,

$\Delta h_{t, c}$ - melting temperature of the sample totally cristal.

To define crystallinity degree the Differential Scanning Calorimetry Method DSC was used. The calorimeters work basing on measures of the heat, used to maintain the tested sample and the chemically neutral pattern of the same temperature. Usually the heating or cooling is applied with constant speed and range. The area between a curve line DSC and the zero line is proportional to the change of enthalpy of the tested sample. In the ideal example, the zero line should be parallel to the time axis $(\mathrm{Q}=0)$. Practically, it is usually turned up or down due to the specific heat changes (or mass) of the sample.

\section{Testing of the polyethylene structure with the Differential Scanning Calorimetry}

The UHMWPE polyethylene used for medical purposes has a complex structure and consists of amorphic and crystal phase. These two phases define mechanical features of polyethylene, and any changes may prove any destructive processes.

In endoprostheses cups the change of cristality degree of polyethylene can be caused by:

- Friction and long time stresses

- Rtg radiation

- Any changes caused by long-term usage processes [3].

Due to the above reasons the following work presents the analysis of the change of crystallinity degree of the samples under the influence of one of the factors [4].

Polyethylene samples in the shapes of cuboid $10 \times 10 \times 20 \mathrm{~mm}$, were submitted to Rtg radiation. The samples of Rtg radiated UHMWPE were tested on the change of crystallinity degree. To do that there was used Differential Scanning Calorimetry Method DSC [6]. Figure 2 shows the measurements results for UHMWPE sample radiated with $90 \mathrm{cGy}$, while Figure 3 for the sample radiated with $150 \mathrm{cGy}$. Figure 4 additionally shows the results of DSC tests for the sample of Chirulen 1020 not submitted to ionic radiation.

Crystallinity degree for particular samples was:

- Sample treated with $90 \mathrm{cGy}-54.2 \%$,

- Sample treated with $150 \mathrm{cGy}-59.2 \%$,

- Sample not treated at all $-48.8 \%$. 


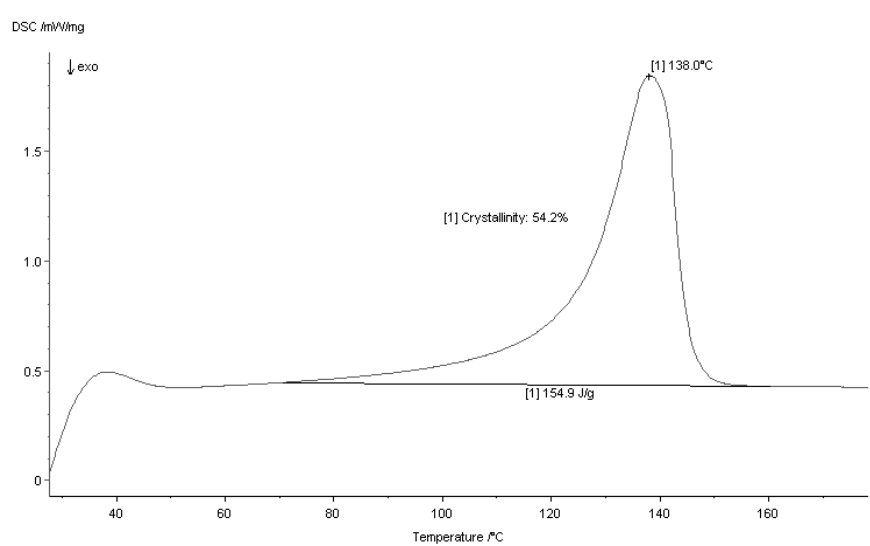

Fig. 2. DSC results for the sample treated with $90 \mathrm{cGy}$

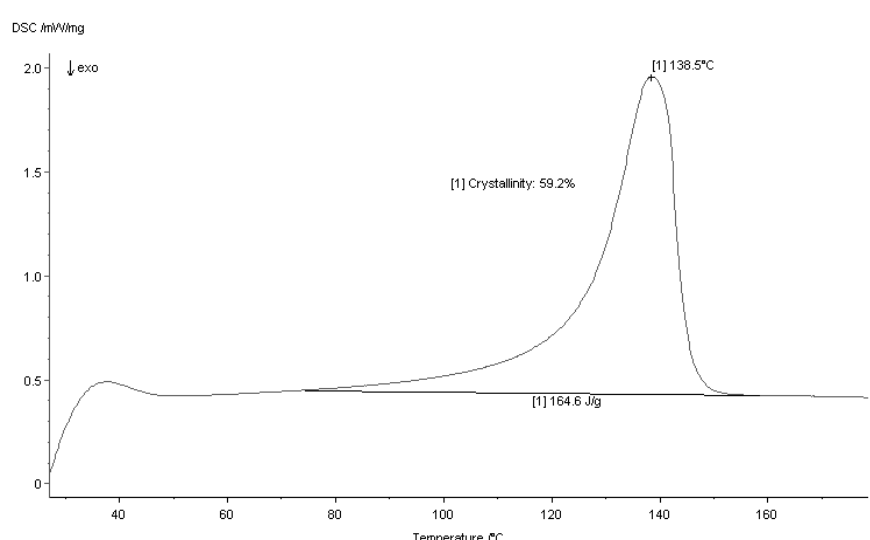

Fig. 3. DSC results for the sample treated with $150 \mathrm{cGy}$

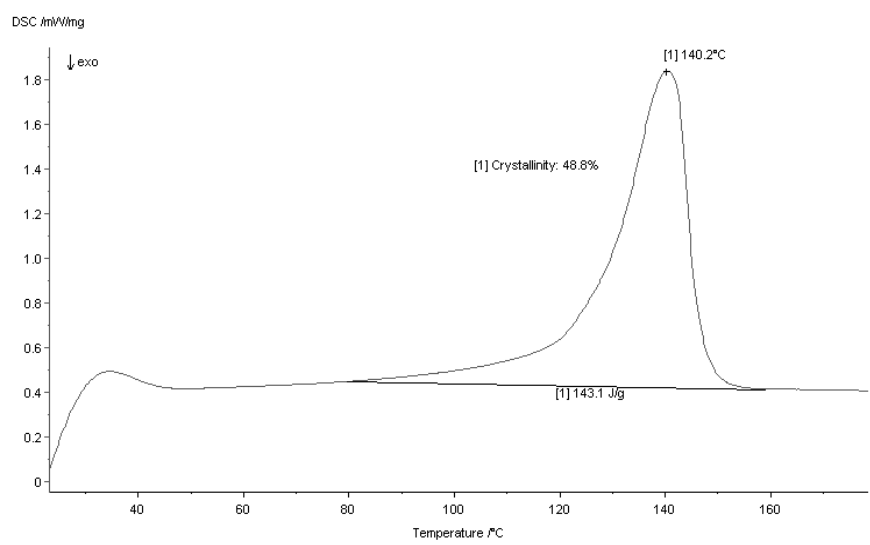

Fig. 4. DSC results for the sample treated with no radiation 
The difference between the results of crystallinity degree is presented in Figure 5.

Basing on the above results it can be stated that the difference between crystallinity degree of the sample treated with $90 \mathrm{cGy}$ (the lowest dosage) and the sample treated with $150 \mathrm{cGy}$ (the highest dosage) is ca. 5\%. Very similar difference of crystallinity degree $(5.4 \%)$ was noticed between not treated sample and the sample treated with $90 \mathrm{cGy}$.

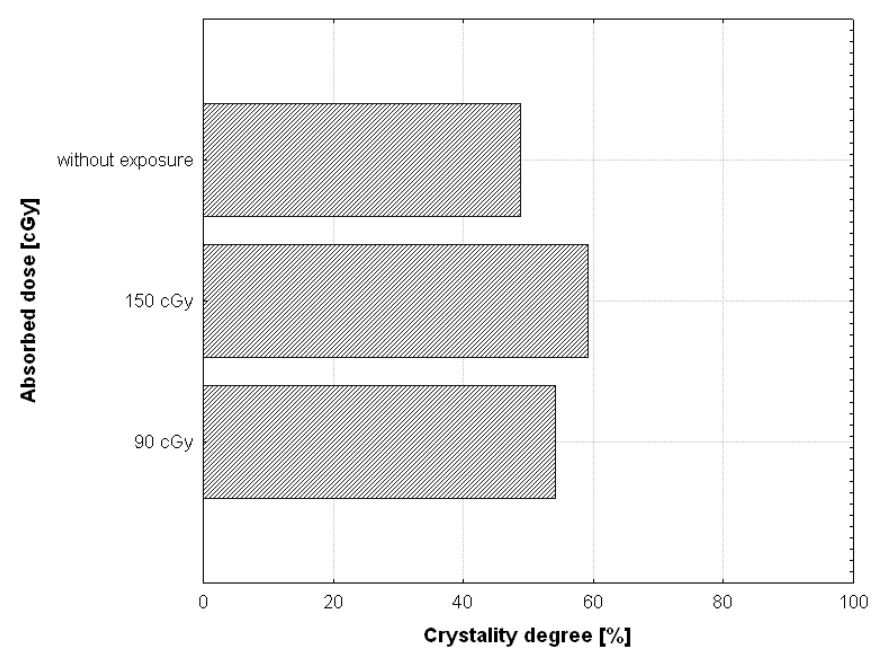

Fig. 5. Crystallinity degree of tested samples

\section{References}

[1] Pielichowski K., Flejtuch K., Zastosowanie modulowanej różnicowej kalorymetrii skaningowej (MDSC) w badaniach właściwości polimerów, Polimery 2002, 47, 11-12.

[2] Balcerowiak W., Różnicowa kalorymetria skaningowa i termograwimetria - aspekty teoretyczne i praktyczne, V Szkoła analizy termicznej, Zakopane 2008.

[3] Gierzyńska-Dolna M., Biotribologia, Wydawnictwo Politechniki Częstochowskiej, Częstochowa 2002.

[4] Projekt badawczy nr 4TO8A04422, Teoretyczno-doświadczalna analiza obciążeń układu ruchowego endoprotez stawu biodrowego ze szczególnym uwzględnieniem badań własności tribologicznych materiałów, 2004.

[5] Szumera M., Charakterystyka wybranych metod termicznych, LAB 2013, 1, 18.

[6] www.netsch.com 